\title{
Effects of local or systemic administration of meloxicam on mammary gland inflammatory responses to lipopolysaccharide-induced mastitis in dairy cows
}

\author{
M. O. Caldeira, ${ }^{1,2} \odot$ R. M. Bruckmaier, ${ }^{1} \odot$ and O. Wellnitz ${ }^{1 *} \odot$ \\ ${ }^{1}$ Veterinary Physiology, Vetsuisse Faculty, University of Bern, 3001 Bern, Switzerland \\ ${ }^{2}$ Graduate School for Cellular and Biomedical Science, University of Bern, 3012 Bern, Switzerland
}

\begin{abstract}
Nonsteroidal anti-inflammatory drugs (NSAID) are commonly used in combination with antimicrobial mastitis treatments to reduce pain. Little is known about whether meloxicam, an NSAID designed for the preferential inhibition of cyclooxygenase- 2 over cyclooxygenase- 1 , affects the mammary immune response. The objective of this study was to analyze the mammary immune response to intramammary (local) or intravenous (systemic) administration of meloxicam with or without immune activation by lipopolysaccharide (LPS). We challenged 108 quarters of 30 cows with or without a low or high dose of LPS from Escherichia coli $(0.1$ or $0.2 \mu \mathrm{g} /$ quarter $)$, with or without meloxicam via intramammary administration $(50 \mathrm{mg} /$ quarter $)$ or intravenous injection $(0.5 \mathrm{mg} / \mathrm{kg}$ of body weight; $\sim 300$ $\mathrm{mg} / \mathrm{cow})$. Intramammary administration of meloxicam alone did not trigger an acute inflammatory response, verified by unchanged somatic cell count (SCC) and lactate dehydrogenase (LDH), BSA, and IgG concentrations in milk, which are normally augmented during mastitis due to an opening of the blood-milk barrier. Similarly, intramammary meloxicam did not change the mRNA abundance of inflammatory factors in mammary gland tissue. As expected, quarters challenged with either dose of LPS showed increased leukocyte infiltration (SCC); increased $\mathrm{LDH}, \mathrm{BSA}, \mathrm{IgG}, \mathrm{Na}$, and $\mathrm{Cl}$ concentrations; and diminished $\mathrm{K}$ concentrations in milk. In contrast to our hypothesis, the addition of intramammary or intravenous meloxicam did not reduce these markers of mastitis in milk. Instead, intramammary meloxicam appeared to accelerate the SCC response to LPS, but only at the lower LPS dose. Moreover, the mRNA expression of inflammatory factors in mammary tissue was not modified by the intramammary application of meloxicam compared with the con-
\end{abstract}

Received April 10, 2020.

Accepted August 28, 2020.

*Corresponding author: olga.wellnitz@vetsuisse.unibe.ch tralateral quarters that were challenged with LPS only. We demonstrated for the first time that intramammary meloxicam at a dose of $50 \mathrm{mg} /$ quarter did not trigger an immune response in the mammary glands of dairy cows. At the doses we used, meloxicam (intramammary or systemic) did not lower inflammatory responses. The intramammary administration of meloxicam seemed to stimulate leukocyte recruitment into the milk in quarters challenged with a low dose of LPS. The integrity of the blood-milk barrier was not protected by meloxicam in LPS-stimulated quarters. This study provides the first indications that meloxicam does not limit the inflammatory response in the mammary gland, although it does not impair the mammary immune system.

Key words: nonsteroidal anti-inflammatory drugs (NSAID), meloxicam, inflammatory response, bloodmilk barrier

\section{INTRODUCTION}

Mastitis in dairy cows is frequently treated with nonsteroidal anti-inflammatory drugs (NSAID), in addition to antimicrobials, to decrease inflammatory response and pain, improving animal welfare (Kayitsinga et al., 2017). In cows diagnosed with mild to moderate clinical mastitis, the addition of the NSAID meloxicam (MEL) to parenteral antibiotic treatment resulted in lower SCC, an increased probability of bacteriological cure, and diminished the likelihood of culling compared with cows treated with antibiotics alone (McDougall et al., 2009, 2016). Furthermore, cows that received MEL in addition to antibiotics as a treatment for mastitis in early lactation showed an improvement in conception rate, resulting in economic benefits for the farmer (van Soest et al., 2018).

Inflammation of the mammary gland is caused mainly by bacterial pathogens entering the teat canal, such as Escherichia coli (Bannerman et al., 2004; Bruckmaier and Wellnitz, 2017). The pathogen-associated molecular pattern LPS from $E$. coli can be used to trigger an immune response comparable to a bacterial intramammary infection (Schmitz et al., 2004). After infusion of 
LPS into the mammary gland, the common effects of mastitis are observed, such as disruption of the bloodmilk barrier. As a consequence, blood components pass to the milk [e.g., SCC, BSA, lactate dehydrogenase (LDH), and immunoglobulins], changing its composition (Wellnitz et al., 2011; Lehmann et al., 2013; Wall et al., 2016). Once the LPS is recognized by pattern recognition receptors, the innate immune system responds by promoting inflammation. This includes an upregulation of proinflammatory cytokines [e.g., tumor necrosis factor (TNF)] and production of chemokines (e.g., interleukins; Lawrence, 2009; Holdsworth and Gan, 2015). As well, the secretion of acute-phase proteins such as serum amyloid A (SAA) increases up to 1000-fold during inflammation (Uhlar and Whitehead, 1999; Cheng et al., 2018), further promoting production of cytokines, increasing the influx of leukocytes to the mammary gland, and facilitating phagocytosis and the clearance of bacterial pathogens (Sordillo, 2018). Mastitis severity, duration, and resolution, as well as restoration of mammary gland function, depend on the efficiency of the innate immune response (Aitken et al., 2011).

Prostaglandins (PG) also play a key role in intramammary infections, acting as proinflammatory mediators. Two cyclooxygenase (COX) isoenzymes, COX-1 and COX-2, participate in the conversion of arachidonic acid to $\mathrm{PGH}_{2}$ (a precursor for $\mathrm{PGE}_{2}$ synthesis). Although COX-1 is constitutively present in most cells, COX-2 is the inflammation-induced form (Gilroy et al., 1999). Nonsteroidal anti-inflammatory drugs are COX inhibitors that block prostaglandin synthesis, alleviating inflammatory symptoms and pain (Tegeder et al., 2001; Ricciotti and FitzGerald, 2011). Intramammary administration of ketoprofen (a nonselective NSAID) in cows challenged with LPS showed positive results in lessening the detrimental effects of mastitis on the blood-milk barrier (Dan et al., 2018). Because nonselective NSAID suppress the constitutive COX-1, side effects such as disturbance of normal gastrointestinal mucosal protective mechanisms are expected, and alternative NSAID have been developed.

Meloxicam is an NSAID designed to be a COX-2-selective inhibitor to avoid the adverse effects of COX-1 binding (Engelhardt et al., 1996a,b). In vitro, MEL suppressed the increase of inflammatory factors at the mRNA level and the $\mathrm{PGE}_{2}$ synthesis of bovine mammary epithelial cells challenged with LPS (Caldeira et al., 2019). In the same study, the authors also reported a decrease in the viability of mammary epithelial cells with the addition of MEL (Caldeira et al., 2019); therefore the possibility of tissue irritation in vivo should be considered. Shock et al. (2018) conducted a field trial with 2,653 cows from 20 different herds and showed that animals treated orally with MEL at $1.0 \mathrm{mg} / \mathrm{kg} \mathrm{BW}$ were less likely to have subclinical mastitis at calving. Moreover, cows treated orally prepartum with MEL had greater milk yield than untreated cows (Swartz et al., 2018).

Intramammary administration is routinely used in dairy farms as a method of delivering treatments to the mammary gland. Besides the practicality of administration through the teat canal, local administration usually requires lower medication doses. The outcomes of systemic administration of MEL combined with antibiotics in cows have been well compiled, but the effect of intramammary MEL administration on immune response in the mammary gland during mastitis is unknown.

Considering the worldwide emphasis on decreasing the use of antibiotics in animal production, the aim of this study was to evaluate the immune response of the mammary gland to local (intramammary) and systemic (intravenous) administration of MEL, with or without different levels of immune activation by LPS. We hypothesized that administration of MEL (intramammary or intravenous) would reduce the inflammatory processes of LPS-induced mastitis and maintain the competence and integrity of the blood-milk barrier.

\section{MATERIALS AND METHODS}

\section{Animals}

The animal trials followed Swiss laws on animal protection, and the Committee of Animal Experiments (Fribourg, Switzerland) approved all procedures involving animals (\#27909). Thirty Holstein dairy cows in mid-lactation (118 \pm 32 DIM) and with milk production $>15 \mathrm{~kg} / \mathrm{d}$ were enrolled in this study. Parities ranged from 2 to 6 . Cow BW averaged $653 \pm 33$ $\mathrm{kg}$. The cows showed no signs of clinical mastitis, and SCC in the quarters of each cow before the experiment were $<150,000$ cells $/ \mathrm{mL}$. Animals were housed at the Agroscope Research Station (Posieux, Switzerland) in tie stalls, fed hay ad libitum plus $1 \mathrm{~kg}$ of energy concentrate daily, and had free access to water. Cows were milked twice daily at 0530 and $1600 \mathrm{~h}$.

\section{Experimental Design}

Thirty cows were randomly assigned to 1 of 4 experiments (Figure 1A). Six cows each were allocated to experiments 1 to 3 . Twelve cows were allocated to experiment 4 , because it included 3 treatments, requiring 6 pairs of quarters. The front quarters were used for milk sampling, and the rear quarters were used for mammary gland tissue biopsies. 
The treatments administered via the intramammary route were $10 \mathrm{~mL}$ of $0.9 \%$ sterile saline $(\mathbf{C O N}), 50$ mg of meloxicam sodium salt hydrate (Sigma-Aldrich, Buch, Switzerland) diluted in $10 \mathrm{~mL}$ of double-distilled water $\left(\mathbf{M E L}_{\mathrm{imm}}\right.$, as described in Caldeira et al., 2019), $0.1 \mu \mathrm{g} /$ quarter of LPS from E. coli (serotype O26:B6; Sigma-Aldrich) diluted in $10 \mathrm{~mL}$ of $0.9 \%$ sterile saline (LPS-L), and $0.2 \mu \mathrm{g} /$ quarter of LPS from E. coli (serotype O26:B6; Sigma-Aldrich) diluted in $10 \mathrm{~mL}$ of $0.9 \%$ sterile saline (LPS-H). The treatment for intravenous injection was $0.5 \mathrm{mg} / \mathrm{kg}$ BW of meloxicam $\left(\mathbf{M E L}_{\mathrm{iv}}\right.$; Contacera; Zoetis, Delémont, Switzerland) injected into the jugular vein. All treatments were prepared in different syringes with a final volume of $10 \mathrm{~mL}$ each. The treatments were then distributed into the 4 experiments as follows (Figure 1A).

Experiment 1. In experiment 1, the objective was to analyze the local effects of MEL on the mammary gland without immune activation. In each cow, 2 quarters received $\mathrm{CON}$ and the other 2 quarters received $\mathrm{MEL}_{\mathrm{imm}}$. Two biopsies (before and after treatment) were performed in both rear quarters.
Experiment 2. The objectives of experiment 2 and 3 were to understand whether and how MEL affected mammary glands that had been immune-stimulated with different doses of LPS. In experiment 2, all 4 quarters received intramammary infusions of LPS-L, followed by CON (2 quarters) or $\mathrm{MEL}_{\mathrm{imm}}$ (2 quarters). No biopsies were taken in this experiment, because we expected comparable results to experiment 3 .

Experiment 3. In experiment 3, all 4 quarters received intramammary infusions of LPS-H, followed by CON (2 quarters) or $\mathrm{MEL}_{\text {imm }}$ (2 quarters). Two biopsies (before and after treatment) were performed in both rear quarters.

Experiment 4. The objective of this experiment was to report the effects of NSAID on the mammary gland when MEL was delivered systemically. Because this experiment included 3 treatments (see Figure 1A), requiring 6 pairs of quarters, cows in experiment 4 were divided into 2 groups: experiment $4_{\mathrm{TRT}}(\mathrm{n}=6)$ and experiment $4_{\mathrm{CON}}(\mathrm{n}=6)$. In experiment $4_{\mathrm{TRT}}$, the 2 quarters on one side received CON, and the 2 quarters on the other side received intramammary LPS-H,
A Exp. 1

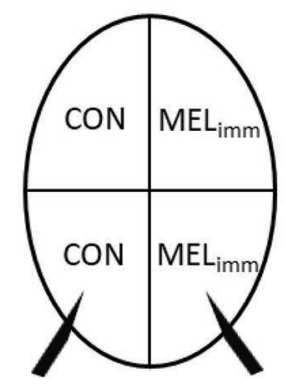

B

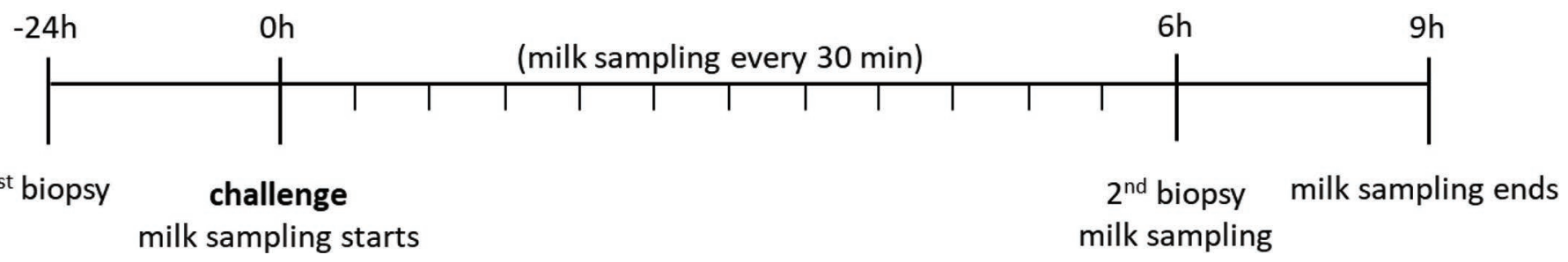

Figure 1. Experimental design. Thirty cows were randomly assigned to 1 of 4 experiments, and treatments were performed in all quarters. The front quarters were reserved for milk samples and the rear quarters for biopsies. (A) In experiment (Exp.) 1, individual mammary quarters were infused with CON (10 mL of $0.9 \%$ sterile saline, intramammary) or $\mathrm{MEL}_{\mathrm{imm}}(50 \mathrm{mg}$ /quarter of meloxicam diluted in $10 \mathrm{~mL}$ of double-distilled water, intramammary). In experiment 2 , individual mammary quarters were infused with LPS-L (0.1 $\mu \mathrm{g} / \mathrm{quarter}$ of LPS from Escherichia coli diluted in $10 \mathrm{~mL}$ of $0.9 \%$ sterile saline, intramammary), followed by CON or $\mathrm{MEL}_{\mathrm{imm}}$. In experiment 3, individual mammary quarters were infused with LPS-H $\left(0.2 \mu \mathrm{g}\right.$ /quarter of LPS from E. coli diluted in $10 \mathrm{~mL}$ of $0.9 \%$ sterile saline, intramammary), followed by CON or MEL imm $_{\text {. }}$ In experiment 4, individual mammary quarters were infused with CON or LPS-H followed by injection of $\mathrm{MEL}_{\mathrm{iv}}(0.5 \mathrm{mg} / \mathrm{kg} \mathrm{BW}$ of meloxicam, intravenous), or mammary quarters were infused with LPS-H only, without MEL $_{\mathrm{iv}}$. (B) Timeline of sample collection. 
followed by a systemic injection of $\mathrm{MEL}_{\mathrm{iv}}(0.5 \mathrm{mg} /$ $\mathrm{kg} \mathrm{BW}$ of meloxicam, i.v.). Two biopsies (before and after treatment) were performed in the rear quarters. In experiment $4_{\mathrm{CON}}, 2$ quarters received intramammary LPS-H, and MEL $_{\text {iv }}$ was not administered.

All intramammary infusions were performed shortly after morning milking $(0 \mathrm{~h})$. Each teat end was scrubbed with $70 \%$ ethanol until clean, and intramammary infusions were administered using a sterile teat cannula. All infusions were followed by a 20 -s massage in the cisternal direction. In experiments 2 and 3, the quarters were first infused with LPS (low or high doses) and then immediately followed by $\mathrm{CON}$ or $\mathrm{MEL}_{\mathrm{imm}}$ infusions. In experiment 4 , the quarters were challenged with $\mathrm{CON}$ or LPS-H concomitantly with the intravenous injection of MEL into the jugular vein.

\section{Milk Sampling and Analyses}

Quarter milk sampling ( $\sim 10 \mathrm{~mL})$ was performed by hand. At $0 \mathrm{~h}$ (before intramammary infusions), milk samples were taken and used as baseline samples. After that, milk samples were collected every 30 min up to $6 \mathrm{~h}$, and at $9 \mathrm{~h}$ post-challenge (Figure 1B). Milk SCC was measured immediately after each collection using a cell counter (DCC; DeLaval, Tumba, Sweden), and then samples were stored at $-80^{\circ} \mathrm{C}$ until further analysis. Milk concentrations of BSA and total IgG were measured in duplicate using a Synergy Mx plate reader (BioTek Instruments, Winooski, VT) and ELISA kits E10-113-39 and E10-118-34 (Bethyl Laboratories, Montgomery, TX), respectively, according to the manufacturer's protocols. Inter- and intraassay coefficients of variation were 3.7 and $7.5 \%$ for BSA and 6.1 and $6.0 \%$ for IgG, respectively.

For the other measurements, the milk was thawed and serum obtained by 2 -step centrifugation: $1,900 \times$ $g$ for $15 \mathrm{~min}$ at $4^{\circ} \mathrm{C}$, and then at $20,800 \times g$ for $30 \mathrm{~min}$ at $4^{\circ} \mathrm{C}$. We determined LDH activity and electrolyte concentrations $(\mathrm{Na}, \mathrm{K}, \mathrm{Cl})$ in milk serum using commercial kits AXON00025 (Axon-Lab AG, Baden, Switzerland) and Mira ISE module DIA50100A1 072008 (Diatools AG, Villmergen, Switzerland), respectively, following the manufacturer's instructions and using an automated analyzer (Cobas Mira; Roche Diagnostics, Basel, Switzerland).

\section{Mammary Gland Tissue Biopsies}

Mammary gland tissue biopsies (approximately $40 \mathrm{mg}$ ) of the rear quarters were taken from cows in experiments 1,3 , and $4_{\mathrm{TRT}}$ at $24 \mathrm{~h}$ before treatment and $6 \mathrm{~h}$ post-challenge. The udders were cleaned and clipped. To avoid injuring large blood vessels and the cisternal region, the biopsy location was carefully selected by sonography. The biopsy site was cleaned and rubbed with $70 \%$ alcohol. Ten minutes before the procedure, the rear quarters received local anesthesia using a subcutaneous injection of $\sim 3 \mathrm{~mL}$ of lidocaine $\mathrm{HCl} 2 \%$ (Streuli Pharma AG, Uznach, Switzerland). A small incision $(\sim 0.5 \mathrm{~cm})$ was made in the skin for easier penetration of the biopsy needle. Two biopsies (at 24 $\mathrm{h}$ before treatment and $6 \mathrm{~h}$ post-challenge) per rear quarter were performed using the Bard Magnum biopsy instrument (Bard GmbH, Karlsruhe, Germany) and a 12 -gauge $\times 13 \mathrm{~cm}$ biopsy needle (Bard Magnum Core Tissue Biopsy Needle; Bard GmbH). For the second mammary tissue biopsy, the angle of the needle entrance was changed slightly to obtain tissue from a close but not disturbed region of the udder. Immediately after acquiring the tissue, samples were placed in an RNA stabilization solution (RNAlater; Invitrogen, Carlsbad, $\mathrm{CA}$ ) and stored at $-80^{\circ} \mathrm{C}$ until RNA extraction.

\section{RNA Extraction and Quantitative Real-Time PCR}

To obtain RNA from the biopsy tissue, samples were placed in a 1.5-mL screw cap microtube (Brand GmbH, Wertheim, Germany) with glass microbeads and $1 \mathrm{~mL}$ of peqGOLD Trifast (PEQLAB Biotechnologie GmbH, Erlangen, Germany). After $5 \mathrm{~min}$ in a homogenizer (Mini-BeadBeater, BioSpec Products, Bartlesville, OK), the majority of the tissue was homogenized and RNA extraction was performed using Direct-zol RNA MiniPrep (Zymo Research Corp., Irvine, CA) following the manufacturer's instructions (https:// files.zymoresearch.com/protocols/_r2050_r2051_r2052 _r2053_direct-zol_rna_miniprep.pdf). Samples were eluted with $20 \mu \mathrm{L}$ of RNA-free water, and total RNA concentrations and purity were determined using a NanoDrop-2000 spectrophotometer (Thermo Fisher Scientific Inc., Waltham, MA) with absorbance at 260 and $280 \mathrm{~nm}$. We determined cDNA concentrations, quantitative real-time PCR, calculation of cycle threshold $(\mathbf{C t})$ values, and normalization of quantitative realtime PCR as previously described by Caldeira et al. (2019). Primer sequences are shown in Table 1. The $\Delta \mathrm{Ct}$ of target genes was normalized using the following equation: $\Delta \mathrm{Ct}=[\mathrm{Ct}$ (gene of interest) $-\mathrm{Ct}$ (mean of housekeeping genes $) \times-1]+20$. The $\Delta \Delta$ Ct was calculated by subtracting the $\Delta \mathrm{Ct}$ of the biopsies $6 \mathrm{~h}$ post-challenge from the $\Delta \mathrm{Ct}$ of the biopsies $24 \mathrm{~h}$ before treatment for each quarter.

\section{Statistical Analyses}

All data were analyzed using SAS (version 9.4; SAS Institute Inc., Cary, NC). Differences were considered 
significant at $P<0.05$, and data are reported as mean \pm standard error of the mean (SEM). The SCC and $\mathrm{LDH}$ measurements were transformed and are presented in a $\log _{10}$ scale. For the milk analyses, we performed a repeated-measurement mixed-model analysis using the MIXED procedure to examine the effects of MEL on SCC, BSA, and IgG concentrations, and on $\mathrm{LDH}$ activity. Each analysis was performed within the respective experiment. The model included treatment, time, and their interaction as fixed effects, and cow as the experimental unit. The repeated statement had cow as the specific term, and the compound symmetry structure was used in the model. Differences between least squares means were determined by Tukey-Kramer test.

To investigate the effects of MEL on the mammary tissue mRNA expression of different pro- and anti- inflammatory factors, we used the TTEST procedure. Factors were evaluated separately, and treatments within experiments were compared as paired observations.

\section{RESULTS}

\section{Milk Composition}

Results of the statistical evaluation of blood-milk barrier integrity and inflammatory markers in milk are presented in Table 2. In all challenged quarters, LPS consistently induced local inflammation and opening of the blood-milk barrier, as indicated by increased SCC and concentrations of blood components (BSA, LDH, and $\operatorname{IgG}$ ) in milk.

Experiment 1. Treatment (CON vs. $\left.\mathrm{MEL}_{\mathrm{imm}}\right)$, time, and their interaction (treatment $\times$ time) had no

Table 1. Primer sequences for PCR, GenBank accession number, annealing temperature, and product size ${ }^{1}$

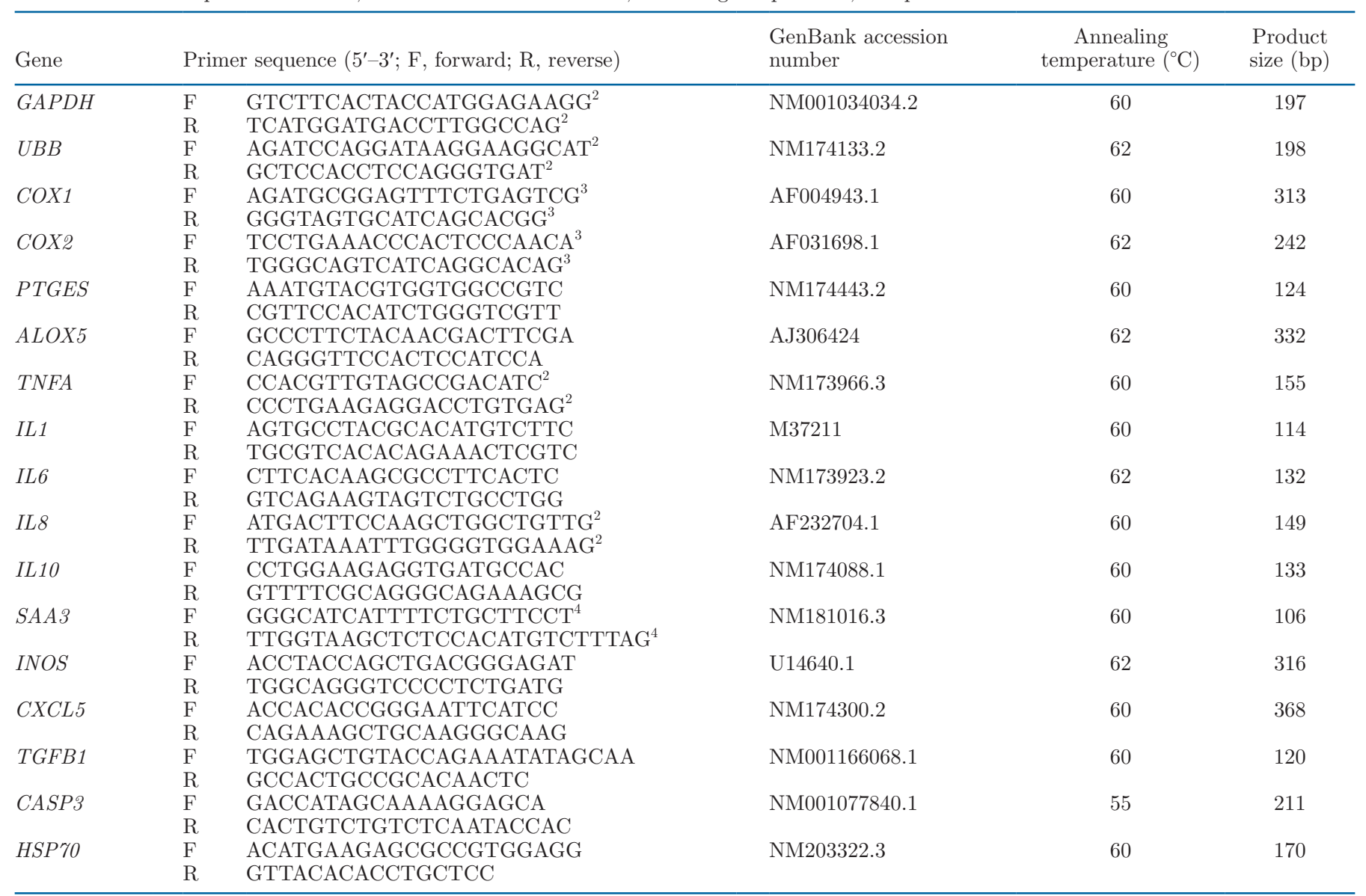

${ }^{1} U B B=$ ubiquitin $\mathrm{B} ; C O X=$ cyclooxygenase $; P T G E S=$ prostaglandin E synthase; $A L O X 5=$ arachidonate 5-lipoxygenase; TNFA = tumor necrosis factor $\alpha: S A A 3=$ serum amyloid A 3; INOS = inducible nitric oxide synthase; $C X C L 5=\mathrm{C}-\mathrm{C}$ motif chemokine ligand 5 ; TGFB1 = transforming growth factor $\beta 1 ; C A S P 3=$ caspase $3 ; H S P 70=$ heat shock protein 70.

${ }^{2}$ Griesbeck-Zilch et al., 2008.

${ }^{3}$ Pfaffl et al., 2003.

${ }^{4}$ Mukesh et al., 2010. 
Table 2. Summary of statistical analysis for milk markers depending on treatment, time, and their interaction

\begin{tabular}{|c|c|c|c|c|c|c|c|c|}
\hline Experiment $^{1}$ & Factor & \multicolumn{7}{|c|}{ Milk marker } \\
\hline \multirow[t]{2}{*}{1} & Treatment & NS & NS & NS & 0.0068 & NS & NS & NS \\
\hline & Treatment $\times$ time & NS & NS & NS & NS & NS & NS & NS \\
\hline \multirow[t]{2}{*}{2} & Treatment & 0.0481 & NS & NS & NS & 0.0331 & NS & NS \\
\hline & Time & $<0.0001$ & $<0.0001$ & 0.001 & 0.0125 & $<0.0001$ & 0.0006 & $<0.0001$ \\
\hline \multirow{2}{*}{3} & Time & $<0.0001$ & $<0.0001$ & $<0.0001$ & $<0.0001$ & $<0.0001$ & $<0.0001$ & $<0.0001$ \\
\hline & Treatment $\times$ time & NS & NS & NS & NS & NS & NS & NS \\
\hline \multirow[t]{3}{*}{4} & Treatment & $<0.0001$ & 0.0033 & 0.0022 & 0.0045 & - & - & - \\
\hline & Time & $<0.0001$ & $<0.0001$ & 0.0299 & NS & - & - & - \\
\hline & Treatment $\times$ time & $<0.0001$ & $<0.0001$ & 0.0191 & 0.0393 & - & - & - \\
\hline
\end{tabular}

${ }^{1}$ Treatments: experiment 1, CON (saline solution, intramammary) versus $\mathrm{MEL}_{\mathrm{imm}}(50 \mathrm{mg} /$ quarter of meloxicam diluted in double-distilled water, intramammary); experiment 2, LPS-L $\left(0.1 \mu \mathrm{g}\right.$ /quarter of LPS from Escherichia coli, intramammary) followed by CON or MEL $\mathrm{imm}_{\text {; }}$ experiment 3, LPS-H $\left(0.2 \mu \mathrm{g}\right.$ /quarter of LPS from E. coli, intramammary) followed by CON or MEL $_{\text {imm }}$; experiment 4, CON or LPS-H, followed by MEL ${ }_{\mathrm{iv}}$ (0.5 mg/kg BW of meloxicam, intravenous) or LPS-H without MEL $\mathrm{iv}_{\text {iv }}$ (included in SCC and LDH only).

${ }^{2} \mathrm{LDH}=$ lactate dehydrogenase.

NS: $P>0.05$.

significant effect on SCC, LDH, or BSA (Figures 2A, $3 \mathrm{~A}$, and $4 \mathrm{~A}$, respectively). The IgG concentrations were greater (Figure 5A) in milk from quarters infused with CON $(0.35 \pm 0.03 \mathrm{mg} / \mathrm{mL})$ versus $\mathrm{MEL}_{\mathrm{imm}}(0.31 \pm$ $0.02 \mathrm{mg} / \mathrm{mL})$. Electrolytes $(\mathrm{Na}, \mathrm{K}$, and $\mathrm{Cl}$ ) were not affected by treatment or the treatment $\times$ time interaction. However, time significantly affected milk Na, $\mathrm{K}$, and $\mathrm{Cl}$ concentrations (Table 2 and Figure 6 ). The concentration of $\mathrm{Na}$ increased (Figure $6 \mathrm{~A}$ ) and that of $\mathrm{K}$ decreased (Figure 6D) at $0.5 \mathrm{~h}(\mathrm{Na}: 34.33 \pm 3.36$ $\mathrm{mmol} / \mathrm{L}$ and $\mathrm{K}: 31.12 \pm 1.50 \mathrm{mmol} / \mathrm{L})$ compared with $0 \mathrm{~h}(\mathrm{Na:} 22.42 \pm 3.36 \mathrm{mmol} / \mathrm{L}$ and $\mathrm{K}: 37.41 \pm 1.50$ $\mathrm{mmol} / \mathrm{L} ; P<0.02)$.

Experiment 2. The interaction of treatment $\times$ time did not differ (Table 2) for SCC, BSA, IgG (Figure $2 \mathrm{~B}, 4 \mathrm{~B}$, and $5 \mathrm{~B}$, respectively), or electrolytes (Figure $6 \mathrm{~B}, 6 \mathrm{E}$, and $6 \mathrm{H})$. At $9 \mathrm{~h}$ post-challenge, LDH concentrations were significantly different $(P<0.01$; Figure 3B) between treatments (LPS-L + CON: $5.74 \pm 0.21$ $\log _{10} \mathrm{U} / \mathrm{L}$ vs. LPS-L $\left.+\mathrm{MEL}_{\mathrm{imm}}: 6.12 \pm 0.28 \log _{10} \mathrm{U} / \mathrm{L}\right)$. We found an overall treatment effect on SCC: LPS-L + $\mathrm{MEL}_{\mathrm{imm}}$ quarters $\left(5.85 \pm 0.09 \log _{10} / \mathrm{mL}\right)$ had a greater SCC $(P<0.05)$ than LPS-L + CON quarters $(5.71$ $\left.\pm 0.06 \log _{10} / \mathrm{mL}\right)$. Compared with the baseline $(0 \mathrm{~h})$, SCC was significantly greater $(P<0.05)$ at 6 and 9 $\mathrm{h}$ in LPS-L + CON quarters, but SCC was elevated in LPS-L + MEL $\mathrm{Mmm}_{\mathrm{imm}}$ quarters at $3.5 \mathrm{~h}$ and $4.5 \mathrm{~h}$, and until $9 \mathrm{~h}$ (Figure 3B). We found an overall treatment effect $(P=0.03$; Table 2$)$ on Na concentrations (Figure $6 \mathrm{~B})$, showing that LPS-L + MEL $_{\text {imm }}$ quarters (40.38 $\pm 2.16 \mathrm{mmol} / \mathrm{L}$ ) had higher $\mathrm{Na}$ concentrations than LPS-L + CON quarters $(34.34 \pm 1.51 \mathrm{mmol} / \mathrm{L})$. Time significantly influenced all milk components in response to LPS stimulation (Table 2). The electrolytes $\mathrm{Na}$ and $\mathrm{Cl}$ were increased at $9 \mathrm{~h}(61.75 \pm 5.25$ and $57.42 \pm$ $3.05 \mathrm{mmol} / \mathrm{L}$, respectively), but $\mathrm{K}$ was decreased at $9 \mathrm{~h}$ $(27.21 \pm 2.65 \mathrm{mmol} / \mathrm{L})$ compared with $0 \mathrm{~h}(\mathrm{Na}: 36.60$ $\pm 5.40 \mathrm{mmol} / \mathrm{L}, \mathrm{Cl}: 39.82 \pm 3.18 \mathrm{mmol} / \mathrm{L}$, and $\mathrm{K}: 34.40$ $\pm 2.68 \mathrm{mmol} / \mathrm{L} ; P<0.02$; Figure 6 ).

Experiment 3. Treatment (LPS-H + CON vs. LPS$\mathrm{H}+\mathrm{MEL})$, and treatment $\times$ time had no effect on the milk constituents evaluated (Figures 2 to 6 ). We found a time effect for all analyzed milk components (Table 2) in response to the immune activation by LPS. In both treatments, SCC increased from $3.5 \mathrm{~h}$ and remained high until $9 \mathrm{~h}$ post-challenge (Figure 2C) compared with baseline $(0 \mathrm{~h} ; P<0.0001)$. For $\mathrm{LDH}$, this effect was seen only at $9 \mathrm{~h}$ post-challenge (Figure $3 \mathrm{C}$ ), but for $\operatorname{IgG}$, it occurred at specific time points $(3,4$, and $9 \mathrm{~h}$ post-challenge; Figure $5 \mathrm{C})$ compared with $0 \mathrm{~h}(P$ $<0.05)$. For the electrolytes, we found an overall time effect on $\mathrm{Na}, \mathrm{Cl}$, and $\mathrm{K}(P<0.0001$; Figure $6 \mathrm{C}, 6 \mathrm{~F}$, and $6 \mathrm{I})$. The $\mathrm{Na}$ and $\mathrm{Cl}$ concentrations in milk were increased $(P<0.05)$ at $9 \mathrm{~h}(49.67 \pm 3.69$ and 49.92 $\pm 3.83 \mathrm{mmol} / \mathrm{L}$, respectively) compared with baseline, and $\mathrm{K}$ concentrations were decreased $(P<0.05)$ at $9 \mathrm{~h}$ $(29.14 \pm 1.65 \mathrm{mmol} / \mathrm{L})$ compared with $0 \mathrm{~h}(\mathrm{Na}: 24.75$ $\pm 3.69 \mathrm{mmol} / \mathrm{L}, \mathrm{Cl}: 34.83 \pm 3.83 \mathrm{mmol} / \mathrm{L}$, and $\mathrm{K}: 36.99$ $\pm 1.64 \mathrm{mmol} / \mathrm{L}$, respectively).

Experiment 4. The SCC was similar $(P=0.16)$ in quarters with LPS-H $+M_{\text {MEL }}$ and LPS-H only. Both treatments had statistically greater SCC from 3 $\mathrm{h}\left(\mathrm{LPS}-\mathrm{H}+\mathrm{MEL}_{\mathrm{iv}}\right)$ and $3.5 \mathrm{~h}(\mathrm{LPS}-\mathrm{H})$ post-challenge until the end of the experiment $(9 \mathrm{~h})$ compared with $\mathrm{CON}+\mathrm{MEL}_{\mathrm{iv}}(P<0.0001$; Figure 2D). Compared with baseline $(0 \mathrm{~h}), \mathrm{SCC}$ in the mammary quarters that 

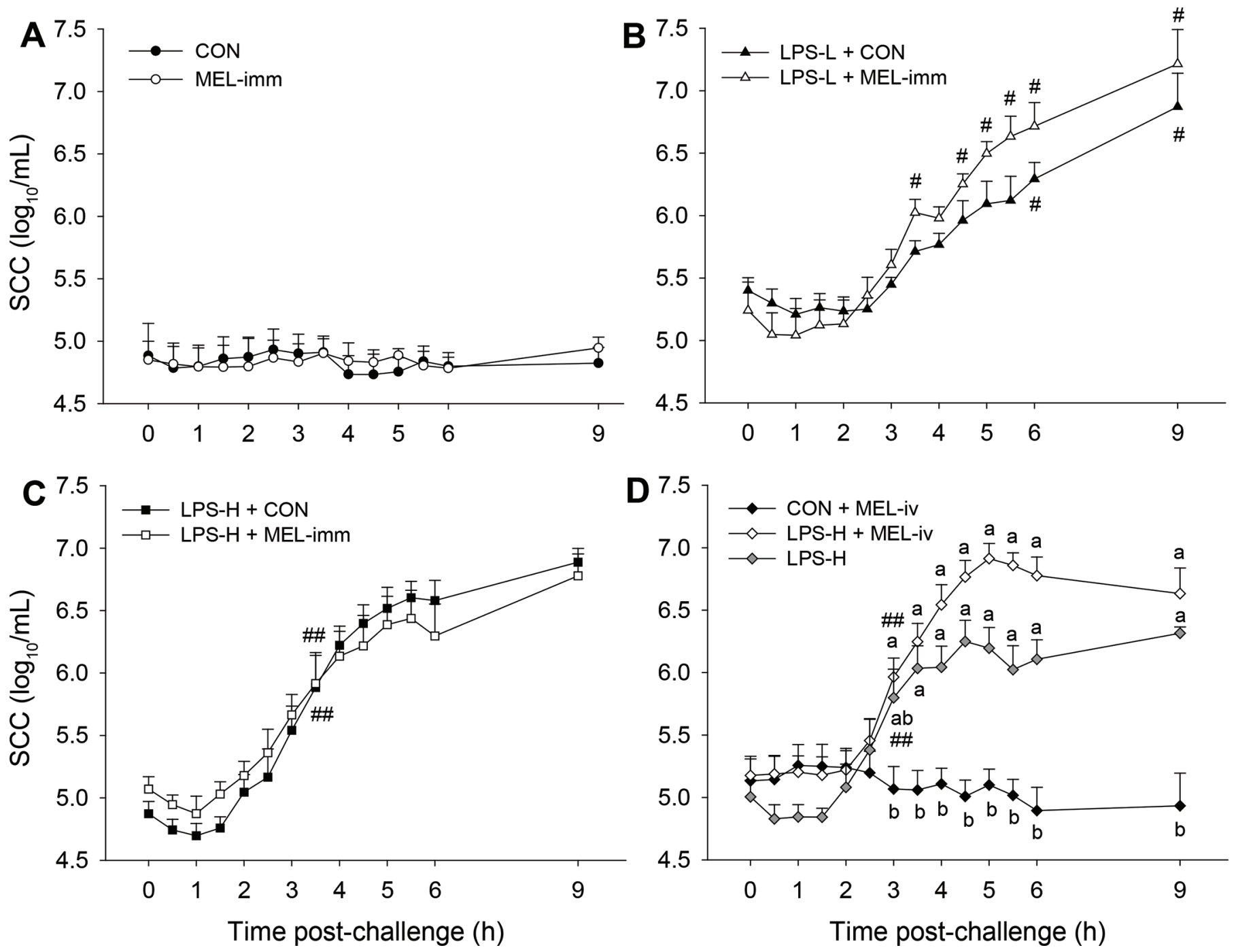

Figure 2. Milk SCC (mean \pm SEM) presented in log scale. All treatments were performed at $0 \mathrm{~h}$ after milk sample collection. (A) In experiment 1 , individual mammary quarters were infused with CON (saline solution, intramammary) or $\mathrm{MEL}_{\text {imm }}(50 \mathrm{mg} / \mathrm{quarter}$ of meloxicam diluted in double-distilled water, intramammary). (B) In experiment 2, individual mammary quarters were infused with LPS-L $(0.1 \mu \mathrm{g} /$ quarter of LPS from Escherichia coli, intramammary), followed by CON or MEL $_{\mathrm{imm}}$. (C) In experiment 3, individual mammary quarters were infused with LPS-H $\left(0.2 \mu \mathrm{g} /\right.$ quarter of LPS from E. coli, intramammary), followed by CON or MEL $\mathrm{Mmm}_{\text {. }}$ (D) In experiment 4, individual mammary quarters were infused with CON or LPS-H followed by injection of $\mathrm{MEL}_{\mathrm{iv}}(0.5 \mathrm{mg} / \mathrm{kg}$ BW of meloxicam, intravenous $)$, or mammary quarters were infused with LPS-H only, without MEL $\mathrm{i}_{\mathrm{i}}$. Different letters ( $\mathrm{a}$ and b) represent a significant treatment effect within a time point; \# indicates a significant difference compared with baseline $(0 \mathrm{~h})$; \#\# indicates a time point of significant elevation (compared with $0 \mathrm{~h}$ ) until the end of the experiment. Significance was declared at $P<0.05$.

received LPS-H started increasing at $3 \mathrm{~h}$ and remained elevated until the end of the experiment $(P<0.05)$, as expected after LPS challenges. The LDH concentrations

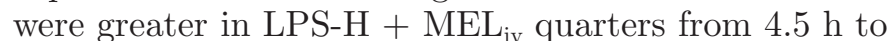
$6 \mathrm{~h}$ post-challenge and in LPS-H at $9 \mathrm{~h}$ post-challenge, both compared with $\mathrm{CON}+\mathrm{MEL}_{\mathrm{iv}}$ quarters $(P<$ 0.0001; Figure 3D). We detected a treatment $\times$ time difference (LPS-H + MEL $_{\text {iv }}$ vs. CON + MEL $_{\text {iv }}$ ) only in BSA and IgG concentrations at $4.5 \mathrm{~h}$ post-challenge $(P<0.05$; Figures $4 \mathrm{D}$ and $5 \mathrm{D}$, respectively $)$. At $4.5 \mathrm{~h}$, BSA $(1.19 \pm 0.50 \mathrm{mg} / \mathrm{mL})$ and $\operatorname{IgG}(0.88 \pm 0.25 \mathrm{mg} /$
$\mathrm{mL}$ ) concentrations in LPS-H $+\mathrm{MEL}_{\text {iv }}$ quarters were significantly greater $(P<0.05)$ than at $0 \mathrm{~h}(0.20 \pm 0.04$ and $0.37 \pm 0.07 \mathrm{mg} / \mathrm{mL}$, respectively). Unfortunately, the BSA and IgG results for LPS-H could not be evaluated, because samples were lost.

\section{Mammary Gland Gene Expression}

Results of the gene expression $(\Delta \Delta \mathrm{Ct})$ of pro- and anti-inflammatory factors analyzed in the mammary gland tissue collected from experiment 1 (CON vs. 

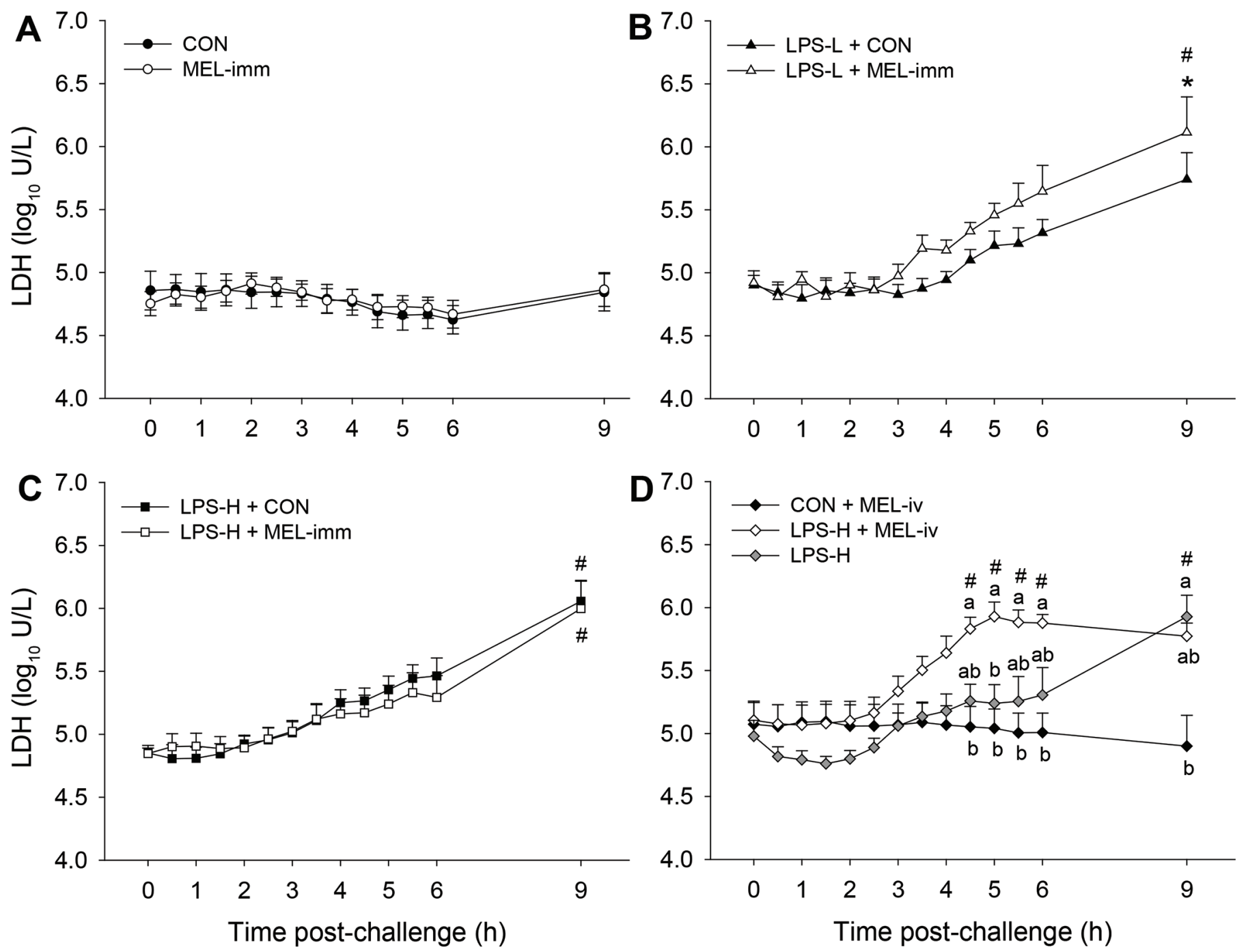

Figure 3. Milk lactate dehydrogenase (LDH; mean \pm SEM) presented in log scale. All treatments were performed at $0 \mathrm{~h}$ after milk sample

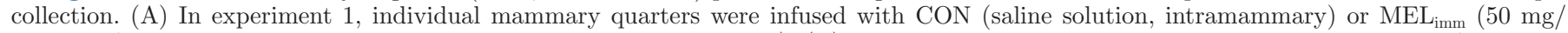
quarter of meloxicam diluted in double-distilled water, intramammary). (B) In experiment 2, individual mammary quarters were infused with

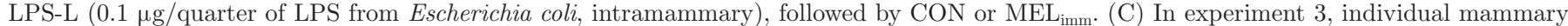
quarters were infused with LPS-H $\left(0.2 \mu \mathrm{g}\right.$ /quarter of LPS from E. coli, intramammary), followed by CON or MEL $\mathrm{imm}_{\text {. }}$ (D) In experiment 4 , individual mammary quarters were infused with CON or LPS-H followed by injection of MEL $\mathrm{iv}_{\mathrm{s}}(0.5 \mathrm{mg} / \mathrm{kg}$ BW of meloxicam, intravenous), or mammary quarters were individually infused with LPS-H only, without MEL $_{\mathrm{iv}}$. Different letters (a and b) represent a significant treatment effect within a time point; \# indicates a significant difference compared with baseline $(0 \mathrm{~h})$. Significance was declared at $P<0.05$. ${ }^{*}$ represents a significant treatment effect within a time point.

$\mathrm{MEL}_{\mathrm{imm}}$ ), experiment 3 (LPS-H + CON vs. LPS-H + $\left.\mathrm{MEL}_{\mathrm{imm}}\right)$, and experiment $4\left(\mathrm{CON}+\mathrm{MEL}_{\mathrm{iv}}\right.$ vs. LPS-H $\left.+\mathrm{MEL}_{\mathrm{iv}}\right)$ are presented in Table 3.

Other than increased mRNA abundance of IL6 $(P=$ 0.01; Table 3) and HSP7O $(P=0.02$; Table 3$)$ in the MEL-treated mammary glands compared with CON, we found no other significant differences in experiment $1(P>0.05)$. In experiment 3 , the mRNA abundance of all factors analyzed was similar between LPS-H + CON and LPS-H + MEL $_{\text {imm }}$ quarters. In experiment 4 , the mRNA expression of TNFA $(P=0.02), I L 1(P=0.02)$, and IL10 $(P=0.01)$ was upregulated and the mRNA expression of COX1 $(P=0.04)$ was downregulated in LPS-H + MEL $_{\text {iv }}$ quarters compared with CON + ME$\mathrm{L}_{\mathrm{iv}}$ quarters (Table 3 ).

\section{DISCUSSION}

To our knowledge, our study was the first to examine the short-term effects of local meloxicam administration on the immune system of the mammary gland and to relate these results to standard systemic MEL 
administration. On dairy farms, the intramammary administration of medication is common practice because it is easy, safe, and requires lower labor intensity than intravenous drug administration. Furthermore, local administration usually requires a lower dose of the drug.

The intramammary administration of meloxicam at a dose of $50 \mathrm{mg} /$ quarter without additional LPS challenge did not activate an immune response in itself: SCC, IgG and BSA concentrations, and LDH activity in milk - which are typically augmented when the immune system is triggered (Wellnitz et al., 2010, 2011, 2013) - remained unchanged. In addition, gene expres- sion of key inflammatory factors such as TNF- $\alpha$, IL-8, SAA3, and INOS were similar in $\mathrm{MEL}_{\text {imm }}$ and CON quarters. Only the mRNA abundance of the cytokine IL-6 and HSP70 were upregulated in treated quarters, which may indicate a slight immunological response of mammary tissue to the intramammary application of MEL. At the dose we used, MEL alone did not cause a local inflammatory reaction in mammary gland tissue. The selected intramammary dose of $50 \mathrm{mg}$ was approximately one-sixth of the intravenous dosage $(0.5 \mathrm{mg} / \mathrm{kg}$ of BW); however, the distribution of MEL throughout the body after intramammary administration is not yet known. Our results confirm those of an earlier in vitro
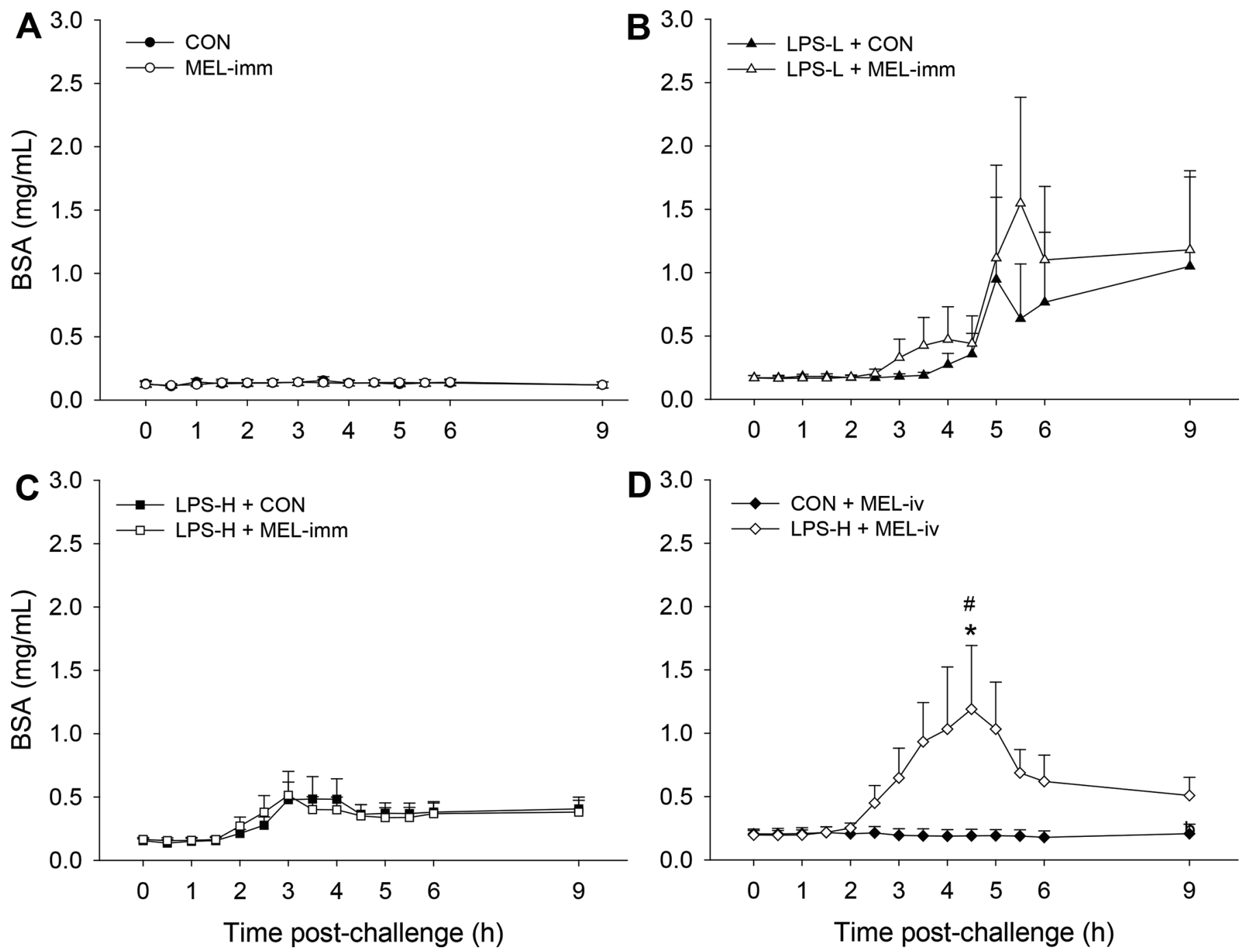

Figure 4. Milk BSA concentrations (mean \pm SEM). All treatments were performed at $0 \mathrm{~h}$ after milk sample collection. (A) In experiment 1 , individual mammary quarters were infused with CON (saline solution, intramammary) or $\mathrm{MEL}_{\text {imm }}$ (50 mg/quarter of meloxicam diluted in double-distilled water, intramammary). (B) In experiment 2, individual mammary quarters were infused with LPS-L (0.1 $\mu \mathrm{g} /$ quarter of LPS from Escherichia coli, intramammary), followed by $\mathrm{CON}_{\text {or }} \mathrm{MEL}_{\mathrm{imm}}$. (C) In experiment 3, individual mammary quarters were infused with LPS-H $\left(0.2 \mu \mathrm{g} /\right.$ quarter of LPS from E. coli, intramammary), followed by CON or MEL $\mathrm{imm}_{\mathrm{imm}}$. (D) In experiment 4, individual mammary quarters were infused with CON or LPS-H followed by injection of $\mathrm{MEL}_{\mathrm{iv}}(0.5 \mathrm{mg} / \mathrm{kg}$ BW of meloxicam, intravenous $)$. \# indicates a significant difference compared with baseline $(0 \mathrm{~h}) ;{ }^{*}$ represents a significant treatment effect within a time point. Significance was declared at $P<0.05$. 
experiment, in which mammary epithelial cells were cultivated in the presence of different doses of MEL, with or without stimulation by bacterial antigens, and the NSAID alone did not activate an immune response (i.e., increased cytokine expression; Caldeira et al., 2019).

The LPS challenge is a model of mastitis comparable to an infection with a maximal stimulus at the time of LPS infusion. Therefore, we administered meloxicam and LPS simultaneously. Cows did not develop fever (data not shown) after the LPS challenge, indicating that the immune activation was restricted to the mammary gland. As expected, all quarters challenged with LPS responded with an increase in milk SCC, in agreement with previous work (Wellnitz et al., 2011). Contrary to our hypothesis, intramammary infusion of MEL did not diminish leukocyte infiltration (measured as SCC) into quarters that received LPS-H or

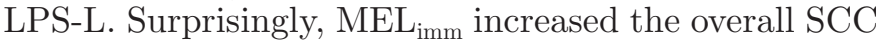
response, but only at the LPS-L dose, even though MEL alone (without an additional LPS challenge) did not induce a greater SCC. This could indicate that intramammary MEL may stimulate leukocyte recruitment into the mammary gland, improving its immune competence, but only if the immune system is already activated. We speculate that after the challenge with
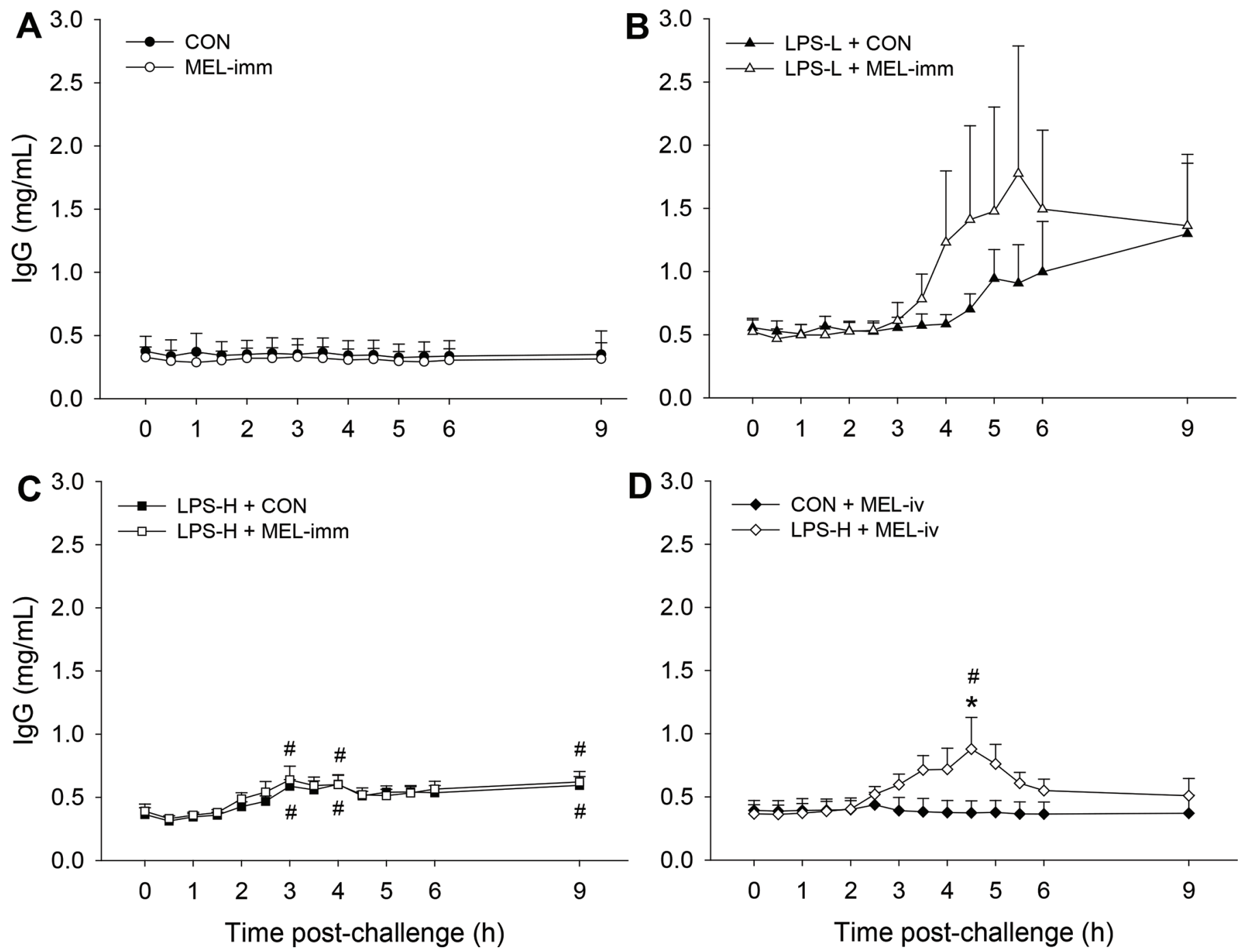

Figure 5. Milk IgG concentrations (mean $\pm \mathrm{SEM}$ ). All treatments were performed at $0 \mathrm{~h}$ after milk sample collection. (A) In experiment 1 , individual mammary quarters were infused with CON (saline solution, intramammary) or $\mathrm{MEL}_{\text {imm }}(50 \mathrm{mg} /$ quarter of meloxicam diluted in double-distilled water, intramammary). (B) In experiment 2, individual mammary quarters were infused with LPS-L $(0.1 \mu \mathrm{g} /$ quarter of LPS from Escherichia coli, intramammary), followed by CON or $\mathrm{MEL}_{\mathrm{imm}}$. (C) In experiment 3, individual mammary quarters were infused with LPS-H $\left(0.2 \mu \mathrm{g}\right.$ /quarter of LPS from E. coli, intramammary), followed by CON or $\mathrm{MEL}_{\mathrm{imm}}$. (D) In experiment 4, individual mammary quarters were infused with CON or LPS-H followed by injection of $\mathrm{MEL}_{\mathrm{iv}}(0.5 \mathrm{mg}$ of meloxicam per kilogram of BW, intravenous). \# indicates a significant difference compared with baseline $(0 \mathrm{~h}) ; *$ represents a significant treatment effect within a time point. Significance was declared at $P<0.05$. 
the LPS-H dose, leukocyte recruitment was already at a maximum and an accelerated increase of SCC could not be detected, but additional research is needed to confirm this hypothesis.

As demonstrated before, the integrity of the bloodmilk barrier is affected during acute bacterial (Bannerman et al., 2004) or LPS-induced (Wall et al., 2016) mastitis, and as consequence, a transfer of blood constituents into the milk is observed (Lehmann et al., 2013). This includes immunoglobulins (which are increased in milk during mastitis) acting as opsonins to improve recognition and phagocytosis of bacteria by macrophages and neutrophils (Aitken et al.,
2011). Our results showed that in quarters that were immune-activated by LPS, the concentrations of IgG increased over time, but when MEL was administered via intramammary infusion into the same quarters, milk IgG concentrations were not lowered. Moreover, milk concentrations of $\mathrm{LDH}$ and BSA increased over time, showing disruption of the blood-milk barrier in quarters challenged with LPS, with high variations between quarters at the end of the experiment. However, when $M L_{\text {imm }}$ was added to the LPS challenge, it did not prevent the opening of the barrier. These findings differed considerably from those of Dan et al. (2018), who had a similar experimental design to ours, but
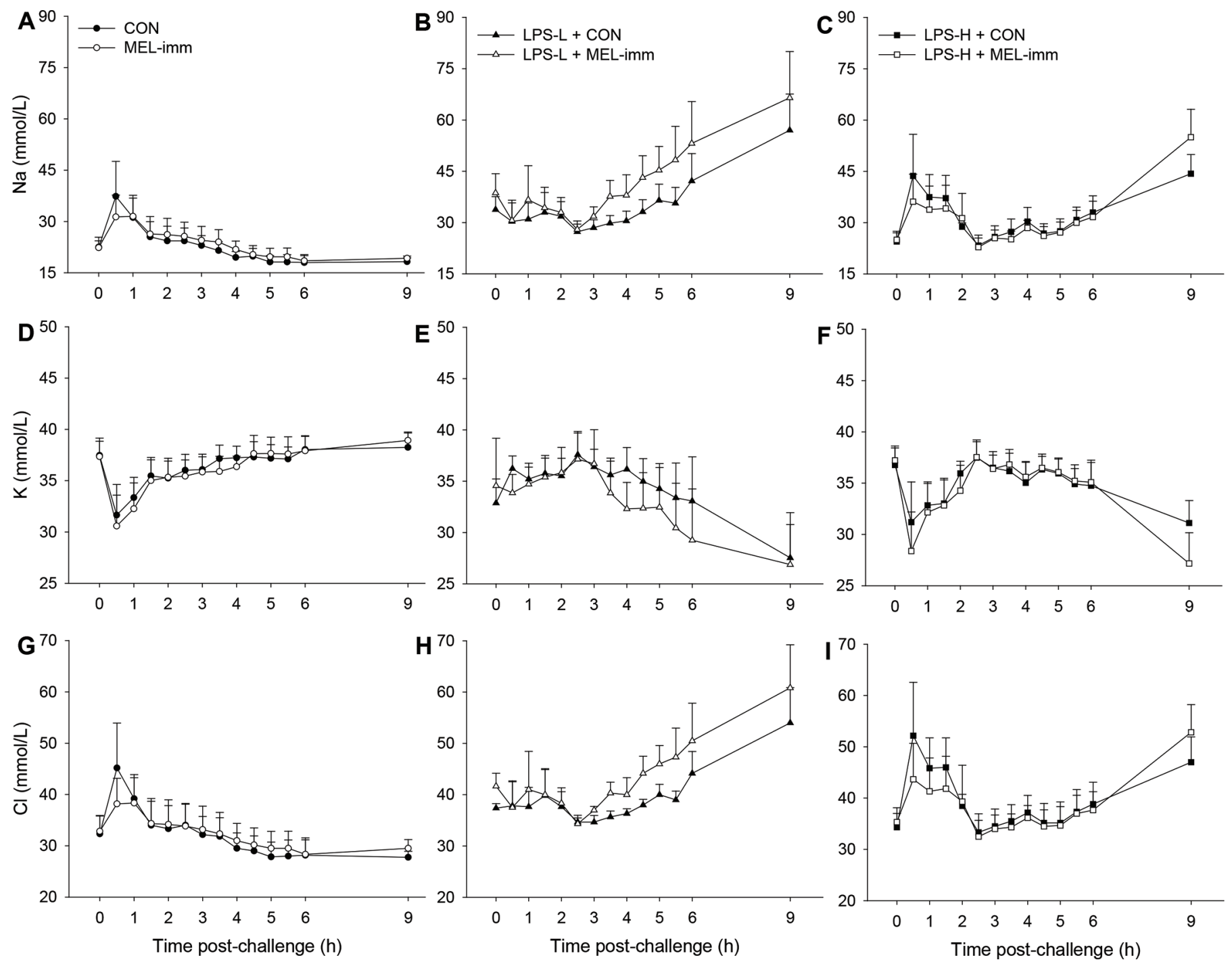

Figure 6. Milk electrolyte concentrations (mean \pm SEM): (A, B, C) Sodium, (D, E, F) potassium, and (G, H, I) chloride. All mammary quarters were challenged at $0 \mathrm{~h}$ after the milk sample collection. (A, D, G) In experiment 1, individual mammary quarters were infused with $\mathrm{CON}$ (saline solution, intramammary) or $\mathrm{MEL}_{\mathrm{imm}}(50 \mathrm{mg} /$ quarter of meloxicam diluted in double-distilled water, intramammary). (B, E, $\mathrm{H}) \mathrm{In}$ experiment 2, individual mammary quarters were infused with LPS-L ( $0.1 \mu \mathrm{g} /$ quarter of LPS from Escherichia coli, intramammary), followed by $\mathrm{CON}$ or $\mathrm{MEL}_{\mathrm{imm}}$. (C, F, I) In experiment 3, individual mammary quarters were infused with LPS-H (0.2 $\mu \mathrm{g} /$ quarter of LPS from $E$. coli, intramammary), followed by $\mathrm{CON}$ or $\mathrm{MEL}_{\mathrm{imm}}$. No significant treatment effect within time points were found $(P>0.05)$. 
Table 3. Relative abundance of mRNA ( $\Delta \Delta$ threshold cycle; mean \pm SEM) in tissue from mammary gland biopsies

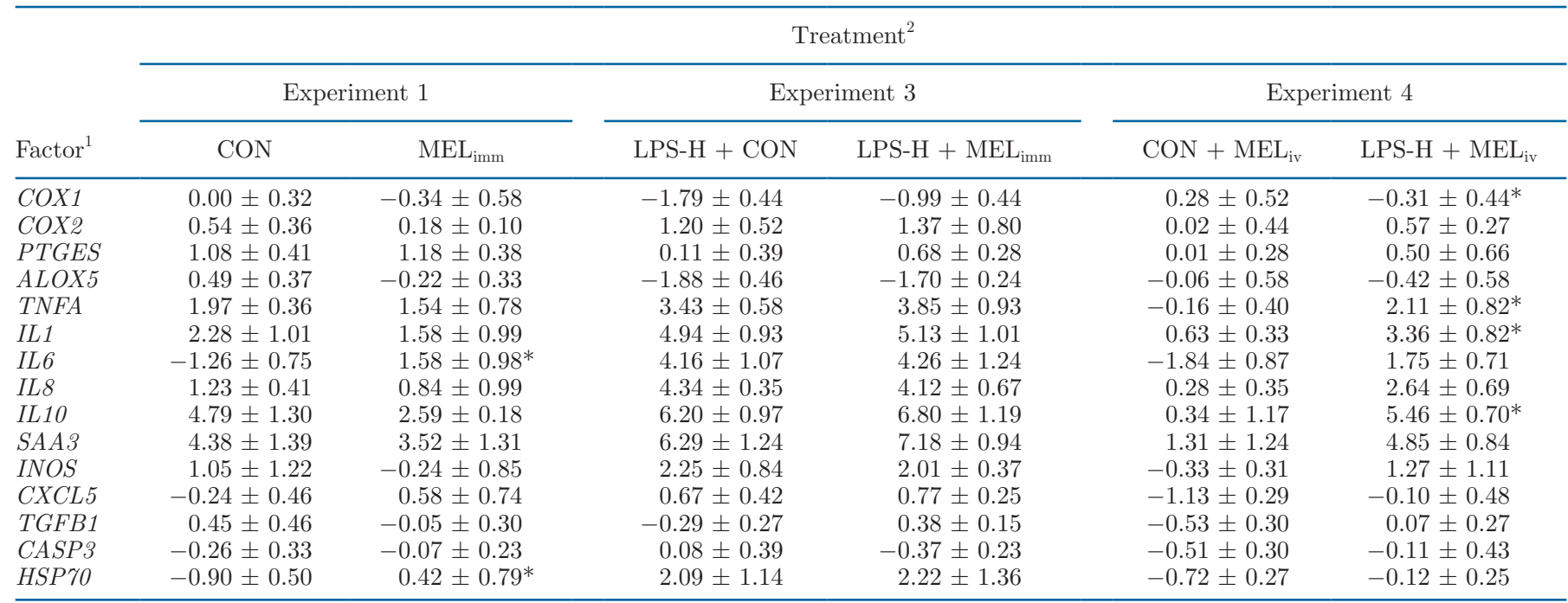

${ }^{1} C O X=$ cyclooxygenase; PTGES = prostaglandin E synthase; $A L O X 5=$ arachidonate 5 -lipoxygenase; TNFA = tumor necrosis factor $\alpha ; S A A 3$ $=$ serum amyloid A 3; INOS = inducible nitric oxide synthase; CXCL5 = C-C motif chemokine ligand $5 ;$ TGFB1 = transforming growth factor $\beta 1 ; C A S P 3=$ caspase $3 ; H S P 70=$ heat shock protein 70.

${ }^{2}$ Treatments: experiment 1, CON (saline solution, intramammary) versus $\mathrm{MEL}_{\mathrm{imm}}(50 \mathrm{mg}$ /quarter of meloxicam diluted in double-distilled water, intramammary); experiment 3, LPS-H $\left(0.2 \mu \mathrm{g}\right.$ /quarter of LPS from Escherichia coli, intramammary) followed by CON or MEL $\mathrm{imm}_{\mathrm{imm}}$; experiment

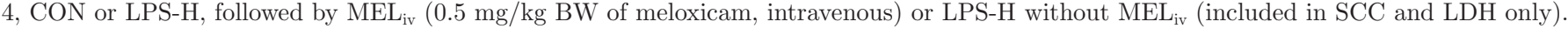

${ }^{*}$ Means within experiments were significantly different $(P<0.05)$.

infused a nonselective NSAID (50 mg of ketoprofen) into quarters that were immune-activated by LPS. In that study, ketoprofen reduced the increase in SCC and maintained the integrity of the blood-milk barrier. The main differences between the 2 mentioned NSAID are COX-binding preference (MEL is selective toward COX-2, and ketoprofen binds to COX-1 and COX-2), bioavailability (orally, MEL $89 \%$ and ketoprofen 100\%), and half-life (15-20 h for MEL and $2 \mathrm{~h}$ for ketoprofen; Calatayud and Esplunges, 2016). Although nothing is known about the bioavailability of these 2 drugs after intramammary administration, these particularities of ketoprofen and MEL may be the reason for the discrepancies in the results of the 2 studies.

Further markers for the integrity of the blood-milk barrier integrity are electrolytes in milk. The relationship between mastitis and milk electrolytes such as $\mathrm{Na}, \mathrm{K}$, and $\mathrm{Cl}$ was well reported by Fernando et al. (1985). In healthy quarters, the ion concentrations of $\mathrm{Na}$ and $\mathrm{Cl}$ in milk is much lower than in blood. During mammary inflammation, due to disruption of the blood-milk barrier, blood components travel freely to the milk, increasing concentrations of $\mathrm{Na}$ and $\mathrm{Cl}$ and decreasing concentrations of $\mathrm{K}$ in milk (Nguyen and Neville, 1998; Bruckmaier et al., 2004). The initial differences ( $0 \mathrm{~h}$ to $0.5 \mathrm{~h}$ post-challenge) of the milk electrolyte concentrations in our experiments likely occurred because of the intramammary infusions of MEL and LPS that were dissolved in $10 \mathrm{~mL}$ of $0.9 \%$ of saline solution or double-distilled water. After this period, our results showed that MEL alone did not change Na, $\mathrm{Cl}$, and $\mathrm{K}$ concentrations, indicating that at a dose of $50 \mathrm{mg} /$ quarter, MEL did not alter the integrity of the blood-milk barrier.

In veterinary practice, NSAIDs are usually administered intravenously, and for this reason, we compared our results from the intramammary administration of MEL to those of intravenous administration. Using the dose of meloxicam recommended for cattle by the manufacturer $(0.5 \mathrm{mg} / \mathrm{kg}$ of BW), we observed no difference between the SCC and $\mathrm{LDH}$ of cows that received $\mathrm{MEL}_{\mathrm{iv}}$ and cows that did not.

McDougall et al. (2009) analyzed the effects of MEL at 7, 14, and $21 \mathrm{~d}$ after NSAID treatment and detected lower SCC when cows received MEL subcutaneously together with intramammary antibiotics. In general, we did not detect lower SCC concentrations after MEL administration. One possible explanation is that our cows challenged with LPS had an SCC above 1 million/ $\mathrm{mL}$ and it may have been that at this threshold, MEL could not counterbalance these harmful effects. As well, our study was designed to evaluate whether MEL played a role in short-term changes $(1 \mathrm{~d})$ in milk components during LPS-induced mastitis. In a more recent study, McDougall et al. (2016) treated cows diagnosed with mild to moderate mastitis with MEL subcutaneously (together with antibiotics) at the same dose as in our experiment $4\left(\mathrm{MEL}_{\mathrm{iv}}\right)$. Similar to our results, the 
authors found no significant change in SCC in cows treated with the NSAID compared with the nontreated cows. When the results of these studies are considered together, intravenous administration of MEL does not markedly affect SCC with respect to the short-term, acute inflammatory response.

The present study shows for the first time the effects on mammary gene expression of intramammary MEL administration to dairy cows. The mRNA abundance of cytokines (TNFA, IL1, IL6, IL10, and TGFB1) and chemokines (IL8 and CXCL5) were similar in quarters that received LPS-H with or without $\mathrm{MEL}_{\mathrm{imm}}$. Contrary to our findings, the addition of MEL in vitro to mammary epithelial cells downregulated the activation of proinflammatory cytokines upon LPS challenge in a dose-dependent manner (Caldeira et al., 2019). Cytokines guide and direct the host's immune response during phagocytosis and bacterial clearance (Aitken et al., 2011). The increase of proinflammatory cytokines in LPS-challenged cells and tissues from the mammary glands of dairy cows has been widely demonstrated in vitro (Wellnitz and Kerr, 2004; Pareek et al., 2005; Dan et al., 2018; Caldeira et al., 2019) and in vivo (Wellnitz et al., 2011; Zarrin et al., 2014). Moreover, the mRNA abundance of analyzed enzymes (COX-1, COX-2, PTGES, ALOX5, INOS, and CASP3), acute-phase protein (SAA3), and heat shock protein (HSP70) - which are important players in the inflammatory response - was not affected by LPS-H with or without $\mathrm{MEL}_{\mathrm{imm}}$. Although MEL inhibits COX-2 function, it did not affect COX2 mRNA expression in mammary cells, indicating that the binding to the protein and inhibition of its function did not influence the level of transcription. This has also been shown in vitro (Caldeira et al., 2019). Accordingly, the lack of effect on proinflammatory gene expression was consistent with the physiological responses found in cows infused with LPS-H. Because we did not perform biopsies in mammary glands that received LPS-L, we could not infer that MEL $_{\text {imm }}$ affects mammary gene expression.

It is also possible that the MEL dose of $50 \mathrm{mg}$ /quarter was not sufficient to affect more proximal regions of the parenchyma. Although NSAID are easily distributed throughout the tissues (Calatayud and Esplunges, 2016), their dilution in the milk that remains in the udder after milking and their unknown bioavailability after intramammary administration do not allow for a precise calculation of MEL concentrations in the mammary parenchyma.

\section{CONCLUSIONS}

In our study, intramammary administration of $50 \mathrm{mg} /$ quarter of MEL did not trigger an immune response in the mammary gland. The simultaneous intramammary administration of MEL with an immune challenge by LPS did not inhibit an increase in SCC in milk and did not contribute to maintaining the integrity of the blood-milk barrier. Meloxicam seemed to promote an earlier increase in SCC response when the mammary gland was stimulated with a lower dose of LPS; however, this finding needs further investigation to verify. The intravenous administration of MEL at the recommended dose by the manufacturer did not diminish SCC in LPS-activated mammary glands. Furthermore, MEL did not vastly alter the mRNA abundance of inflammatory factors in mammary gland tissue. It seems that MEL does not limit the inflammatory response, but it does not impair the mammary immune system.

\section{ACKNOWLEDGMENTS}

We thank Claudine Morel, Yolande Zbinden, and Chantal Philipona (Veterinary Physiology, Vetsuisse Faculty, University of Bern, Switzerland) for their support in the laboratory analyses. The authors have not stated any conflicts of interest.

\section{REFERENCES}

Aitken, S. L., C. M. Corl, and L. M. Sordillo. 2011. Immunopathology of mastitis: Insights into disease recognition and resolution. J. Mammary Gland Biol. Neoplasia 16:291-304. https://doi.org/10 .1007/s10911-011-9230-4.

Bannerman, D. D., M. J. Paape, J.-W. Lee, X. Zhao, J. C. Hope, and P. Rainard. 2004. Escherichia coli and Staphylococcus aureus elicit differential innate immune responses following intramammary infection. Clin. Diagn. Lab. Immunol. 11:463-472. https://doi.org/ 10.1128/CDLI.11.3.463-472.2004

Bruckmaier, R. M., D. Weiss, M. Wiedemann, S. Schmitz, and G. Wendl. 2004. Changes of physicochemical indicators during mastitis and the effects of milk ejection on their sensitivity. J. Dairy Res. 71:316-321. https://doi.org/10.1017/s0022029904000366.

Bruckmaier, R. M., and O. Wellnitz. 2017. Triennial lactation symposium (BOLFA): Pathogen-specific immune response and changes in the blood-milk barrier of the bovine mammary gland. J. Anim. Sci. 95:5720-5728. https://doi.org/10.2527/jas2017.1845.

Calatayud, S., and J. V. Esplunges. 2016. Chemistry, Pharmacodynamics, and Pharmacokinetics of NSAIDs. 1st ed. A. Lanas, ed. Springer International Publishing, Basel, Switzerland.

Caldeira, M. O., R. M. Bruckmaier, and O. Wellnitz. 2019. Meloxicam affects the inflammatory responses of bovine mammary epithelial cells. J. Dairy Sci. 102:10277-10290. https://doi.org/10.3168/jds 2019-16630.

Cheng, N., Y. Liang, X. Du, and R. D. Ye. 2018. Serum amyloid A promotes LPS clearance and suppresses LPS-induced inflammation and tissue injury. EMBO Rep. 19. https://doi.org/10.15252/ embr.201745517.

Dan, D., R. M. Bruckmaier, and O. Wellnitz. 2018. Ketoprofen affects the mammary immune response in dairy cows in vivo and in vitro. J. Dairy Sci. 101:11321-11329. https://doi.org/10.3168/jds .2018-15034.

Engelhardt, G., R. Bögel, C. Schnitzer, and R. Utzmann. 1996a. Meloxicam: Influence on arachidonic acid metabolism: Part I. In vitro findings. Biochem. Pharmacol. 51:21-28. https://doi.org/10 .1016/0006-2952(95)02111-6. 
Engelhardt, G., R. Bögel, C. Schnitzler, and R. Utzmann. 1996b. Meloxicam: Influence on arachidonic acid metabolism: Part II. In vivo findings. Biochem. Pharmacol. 51:29-38. https://doi.org/10 .1016/0006-2952(95)02110-8.

Fernando, R. S., S. L. Spahr, and E. H. Jaster. 1985. Comparison of electrical conductivity of milk with other indirect methods for detection of subclinical mastitis. J. Dairy Sci. 68:449-456. https:/ /doi.org/10.3168/jds.S0022-0302(85)80844-4.

Gilroy, D. W., P. R. Colville-Nash, D. Willis, J. Chivers, M. J. PaulClark, and D. A. Willoughby. 1999. Inducible cyclooxygenase may have anti-inflammatory properties. Nat. Med. 5:698-701. https:// doi.org/10.1038/9550.

Griesbeck-Zilch, B., H. H. D. Meyer, C. H. Kuhn, M. Schwerin, and O. Wellnitz. 2008. Staphylococcus aureus and Escherichia coli cause deviating expression profiles of cytokines and lactoferrin messenger ribonucleic acid in mammary epithelial cells. J. Dairy Sci. 91:2215-2224. https://doi.org/10.3168/jds.2007-0752.

Holdsworth, S. R., and P.-Y. Gan. 2015. Cytokines: Names and numbers you should care about. Clin. J. Am. Soc. Nephrol. 10:22432254. https://doi.org/10.2215/CJN.07590714.

Kayitsinga, J., R. L. Schewe, G. A. Contreras, and R. J. Erskine. 2017. Antimicrobial treatment of clinical mastitis in the eastern United States: The influence of dairy farmers' mastitis management and treatment behavior and attitudes. J. Dairy Sci. 100:1388-1407. https://doi.org/10.3168/jds.2016-11708.

Lawrence, T. 2009. The nuclear factor NF- $\kappa$ B pathway in inflammation. Cold Spring Harb. Perspect. Biol. 1:a001651. https://doi .org/10.1101/cshperspect.a001651.

Lehmann, M., O. Wellnitz, and R. M. Bruckmaier. 2013. Concomitant lipopolysaccharide-induced transfer of blood-derived components including immunoglobulins into milk. J. Dairy Sci. 96:889-896. https://doi.org/10.3168/jds.2012-5410.

McDougall, S., E. Abbeloos, S. Piepers, A. S. Rao, S. Astiz, T. van Werven, J. Statham, and N. Pérez-Villalobos. 2016. Addition of meloxicam to the treatment of clinical mastitis improves subsequent reproductive performance. J. Dairy Sci. 99:2026-2042. https: //doi.org/10.3168/jds.2015-9615.

McDougall, S., M. A. Bryan, and R. M. Tiddy. 2009. Effect of treatment with the nonsteroidal antiinflammatory meloxicam on milk production, somatic cell count, probability of re-treatment, and culling of dairy cows with mild clinical mastitis. J. Dairy Sci. 92:4421-4431. https://doi.org/10.3168/jds.2009-2284.

Mukesh, M., M. Bionaz, D. E. Graugnard, J. K. Drackley, and J. J. Loor. 2010. Adipose tissue depots of Holstein cows are immune responsive: Inflammatory gene expression in vitro. Domest. Anim. Endocrinol. 38:168-178. https://doi.org/10.1016/j.domaniend 2009.10.001.

Nguyen, D. A., and M. C. Neville. 1998. Tight junction regulation in the mammary gland. J. Mammary Gland Biol. Neoplasia 3:233246. https://doi.org/10.1023/a:1018707309361.

Pareek, R., O. Wellnitz, R. Van Dorp, J. Burton, and D. Kerr. 2005. Immunorelevant gene expression in LPS-challenged bovine mammary epithelial cells. J. Appl. Genet. 46:171-177.

Pfaffl, M. W., S. L. Wittmann, H. H. D. Meyer, and R. M. Bruckmaier. 2003. Gene expression of immunologically important factors in blood cells, milk cells, and mammary tissue of cows. J. Dairy Sci. 86:538-545. https://doi.org/10.3168/jds.S0022-0302(03)73632-7.

Ricciotti, E., and G. A. FitzGerald. 2011. Prostaglandins and inflammation. Arterioscler. Thromb. Vasc. Biol. 31:986-1000. https:// doi.org/10.1161/ATVBAHA.110.207449.

Schmitz, S., M. W. Pfaffl, H. H. D. Meyer, and R. M. Bruckmaier. 2004. Short-term changes of mRNA expression of various inflam- matory factors and milk proteins in mammary tissue during LPSinduced mastitis. Domest. Anim. Endocrinol. 26:111-126. https:// doi.org/10.1016/j.domaniend.2003.09.003.

Shock, D. A., D. L. Renaud, S. M. Roche, R. Poliquin, R. Thomson, and M. E. Olson. 2018. Evaluating the impact of meloxicam oral suspension administered at parturition on subsequent production, health, and culling in dairy cows: A randomized clinical field trial. PLoS One 13:e0209236. https://doi.org/10.1371/journal.pone .0209236 .

Sordillo, L. M. 2018. Mammary gland immunobiology and resistance to mastitis. Vet. Clin. North Am. Food Anim. Pract. 34:507-523. https://doi.org/10.1016/j.cvfa.2018.07.005.

Swartz, T. H., H. H. Schramm, J. M. Bewley, C. M. Wood, K. E. Leslie, and C. S. Petersson-Wolfe. 2018. Meloxicam administration either prior to or after parturition: Effects on behavior, health, and production in dairy cows. J. Dairy Sci. 101:10151-10167. https:// doi.org/10.3168/jds.2018-14657.

Tegeder, I., J. Pfeilschifter, and G. Geisslinger. 2001. Cyclooxygenase-independent actions of cyclooxygenase inhibitors. FASEB J. 15:2057-2072. https://doi.org/10.1096/fj.01-0390rev.

Uhlar, C. M., and A. S. Whitehead. 1999. Serum amyloid A, the major vertebrate acute-phase reactant. Eur. J. Biochem. 265:501-523. https://doi.org/10.1046/j.1432-1327.1999.00657.x.

van Soest, F. J. S., E. Abbeloos, S. McDougall, and H. Hogeveen. 2018. Addition of meloxicam to the treatment of bovine clinical mastitis results in a net economic benefit to the dairy farmer. J. Dairy Sci. 101:3387-3397. https://doi.org/10.3168/jds.2017-12869.

Wall, S. K., L. E. Hernández-Castellano, A. Ahmadpour, R. M. Bruckmaier, and O. Wellnitz. 2016. Differential glucocorticoid-induced closure of the blood-milk barrier during lipopolysaccharide- and lipoteichoic acid-induced mastitis in dairy cows. J. Dairy Sci 99:7544-7553. https://doi.org/10.3168/jds.2016-11093.

Wellnitz, O., E. T. Arnold, and R. M. Bruckmaier. 2011. Lipopolysaccharide and lipoteichoic acid induce different immune responses in the bovine mammary gland. J. Dairy Sci. 94:5405-5412. https:// doi.org/10.3168/jds.2010-3931.

Wellnitz, O., E. T. Arnold, M. Lehmann, and R. M. Bruckmaier. 2013. Short communication: Differential immunoglobulin transfer during mastitis challenge by pathogen-specific components. J. Dairy Sci. 96:1681-1684. https://doi.org/10.3168/jds.2012-6150.

Wellnitz, O., A. Baumert, M. Saudenowa, and R. M. Bruckmaier. 2010. Immune response of bovine milk somatic cells to endotoxin in healthy quarters with normal and very low cell counts. J. Dairy Res. 77:452-459. https://doi.org/10.1017/S0022029910000348.

Wellnitz, O., and D. E. Kerr. 2004. Cryopreserved bovine mammary cells to model epithelial response to infection. Vet. Immunol. Immunopathol. 101:191-202. https://doi.org/10.1016/j.vetimm.2004 .04 .019 .

Zarrin, M., O. Wellnitz, H. A. van Dorland, and R. M. Bruckmaier. 2014. Induced hyperketonemia affects the mammary immune response during lipopolysaccharide challenge in dairy cows. J. Dairy Sci. 97:330-339. https://doi.org/10.3168/jds.2013-7222.

\section{ORCIDS}

M. O. Caldeira (®) https://orcid.org/0000-0002-1272-1249

R. M. Bruckmaier ( https://orcid.org/0000-0002-9374-5890

O. Wellnitz ๑ https://orcid.org/0000-0002-5817-3428 